\title{
Morphological Study of Bone Cranial in Athymic Mice
}

\author{
Estudio Morfológico de Hueso Craneal en Ratones Atímicos
}

\author{
Sesman Ana ${ }^{*, * * * * *}$; Ruvalcaba Erika ${ }^{* * * *}$; Herrera Arturo ${ }^{* * * * * * * * * * *}$; Sánchez Guerrero Sergio ${ }^{* * * * * * * * * *}$; Lecona Hugo ${ }^{\text {*******; }}$; \\ Baena-Ocampo Leticia ${ }^{* * * * * *}$; Solis Lilia ${ }^{* * * * * * *}$; Ávila Hector ${ }^{* *}$; García de la Puente Silvestre ${ }^{* * *}$; \\ $\operatorname{Vargas~Betha~}^{* * * * * * *}$; Guerrero Xochitl ${ }^{* * * *}$ \& Velasquillo Cristina ${ }^{* * * *}$
}

SESMAN, A.; RUVALCABA, E.; HERRERA, A.; SÁNCHEZ, G. S.; LECONA, H.; BAENA-OCAMPO, L.; SOLIS, L.; ÁVILA, H.; GARCÍA DE LA PUENTE, S.; VARGAS, B.; GUERRERO, X. \& VELASQUILLO, C. Morphological study of bone cranial in athymic mice. Int. J. Morphol., 31(1):321-328, 2013.

SUMMARY: The aim of our research was to create an osteogenic unit in the skulls of athymic mice; however, the first challenge we faced was to find sufficient and adequate data that would allow us to determine the morphological, immunohistochemical and microtopographical characteristics that could be used as normality standards in athymic mice skulls and, hence, a reference in the event of achieving the formation of de novo bone using the osteogenic unit we proposed. Knowing the normal bone morphology in the skull of athymic mice was a necessary precondition to develop subsequently an osteogenic unit possessing the Osteogenesis, Osteoinduction and Osteoconductivity that could be compared versus those in the normal bone during its formations and remodeling processes. Therefore, we conducted a pilot study to determine bone morphological characteristics in the skull of athymic mice by means of specific histological staining: hematoxylin-eosin and Von Kossa, for osteoid tissue and mineralized bone, and Masson Tri-chrome for ossified areas. We also use immunohistochemistry to detect bone formation markers: alkaline phosphatase resulting from osteoblastic activity stimulation, type 1 collagen a bonematrix structural protein; Osteopontine, a protein specifically synthesized by osteoblasts that favors cell proliferation and remodeling in bone defects; Osteocalcine, a peptide hormone produced by osteoblasts during bone formation; and, Runx 2, a transcription factor expressed by stem cells which stimulates bone differentiation. Likewise, we used electron microscopy on the newly formed tissue to determine the presence of organic deposits, such as calcium, phosphate and magnesium in bone tissue.

KEY WORDS: Osteogenesis; Osteoinduction; Osteoconductivity.

\section{INTRODUCTION}

The scientific community is currently developing the application of biology, chemistry, mathematics, physics and engineering basic principles to design tissue-based materials and material composites to improve or to be used in the surgical reconstruction of injured tissues; these materials try to replicate the basic biological process that take place in different types of tissues (Lorenz et al., 2000; Wozney et al., 1998; Orban et al., 2002). This process is known as biomimethics and the application of said materials to restore, repair, replace and regenerate the tissue's function is called tissue engineering (Mayer et al., 2004). Bone formed through tissue engineering must include a biomimethic extracellular matrix, cells capable of differentiate into osteoblasts and growth factors sending signals that promote cell recruitment, mitosis, differentiation an renewal (Connolly et al., 1989). The matrixes used as scaffolds for cell growth must be absorbable and favor cell anchorage and development and are regularly made of synthetic polymers that, besides complying with these requirements, are easily produced in limitless amounts and can be substituted by cell regeneration thanks to their degradation potential (Eppley, 2001). To this date, there is no synthetic material that complies with all

\footnotetext{
Servicio de Cirugía Plástica Instituto Nacional de Pediatría Cd. México.

** Departamento de Epidemiología Instituto Nacional de Pediatría Cd. México.

**** Departamento de Metodología Investigación Instituto Nacional de Pediatría Cd. México.

**** Unidad de Ingeniería de Tejidos Terapia Celular y Medicina Regenerativa y Biotecnología, Instituto Nacional Rehabilitación Cd. México.

****** Bioterio Instituto Nacional Rehabilitación Cd. México.

******** Departamento de Patología Instituto Nacional Rehabilitación Cd. México.

********* Unidad de Microscopía Electrónica Instituto Nacional Rehabilitación Cd. México.

******** Unidad de Medicina Transfusional Instituto Nacional de Cancerología Cd. México.

********** Departamento de Investigación Hospital General de México. Instituto Nacional de Cancerología Cd. México. This study was partially supported by CONACYT Sectoriales with Grant 114359.
} 
SESMAN, A.; RUVALCABA, E.; HERRERA, A.; SÁNCHEZ, G. S.; LECONA, H.; BAENA-OCAMPO, L.; SOLIS, L.; ÁVILA, H.; GARCÍA DE LA PUENTE, S.; VARGAS, B.; GUERRERO, X. \& VELASQUILLO, C. Morphological study of bone cranial in athymic mice. Int. J. Morphol., 31(1):321-328, 2013.

these requirements; however, several studies are being conducted that will render these technologies available for their clinical application. Once this material is developed, studies on its safety, effectiveness and cost-benefit will be needed (Inoue et al., 1997; Orban et al.).

Nevertheless, before beginning the required research in the area we have proposed, a normality standard must be determined, particularly in bone. The aim of our research was to create an osteogenic unit in the skulls of athymic mice; however, the first challenge we faced was to find sufficient and adequate data that would allow us to determine the morphological, immunohistochemical and microtopographical characteristics that could be used as normality standards in athymic mice skulls and, hence, a reference in the event of achieving the formation of de novo bone using the osteogenic unit we proposed.

Knowing the normal bone morphology in the skull of athymic mice was a necessary precondition to develop subsequently an osteogenic unit possessing the Osteogenesis, Osteoinduction and Osteoconductivity that could be compared versus those in the normal bone during its formations and remodeling processes (Nade et al., 1983; Sonobe et al., 2004; Cornell, 1999). Therefore, we conducted a pilot study to determine bone morphological characteristics in the skull of athymic mice by means of specific histological staining: hematoxylin-eosin and Von Kossa, for osteoid tissue and mineralized bone, and Masson Tri-chrome for ossified areas.

We also use immunohistochemistry to detect bone formation markers: alkaline phosphatase resulting from osteoblastic activity stimulation (Gronthos et al., 1999) type 1 collagen a bone-matrix structural protein (Sweeney et al., 1994). Osteopontine, a protein specifically synthesized by osteoblasts that favors cell proliferation and remodeling in bone defects (Herkowitz, 2004). Osteocalcine, a peptide hormone produced by osteoblasts during bone formation (Herkowitz) and, Runx 2, a transcription factor expressed by stem cells which stimulates bone differentiation (Harris et al., 1994). Likewise, we used electron microscopy on the newly formed tissue to determine the presence of organic deposits, such as calcium, phosphate and magnesium in bone tissue (Basurto et al., 2008).

\section{MATERIALS AND METHOD}

Tissue Sampling. Sampling was carried out in the vivarium operating room under sterility conditions, in the immunocompromised animals unit at the México's National
Rehabilitation Institute. Five athymic mice (aged 5 weeks) were euthanized with pentobarbital overdose. A mid-sagital incision along the antero-superior surface of the skull was made, cutting skin all the way to the pericraneum mid-line. The two flaps so formed (skin and pericraneum) were dissected y bilaterally elevated. An $8 \times 8 \mathrm{~mm}$ craneotomy was performed and placed in a sterile tube with $5 \mathrm{~mL}$ formaldehyde and buffer for its further processing.

Scanning Electron Microscopy. We used scanning electron microscopy to determine the presence of calcification using the X-ray dispersion technique described by Basurto. (Basurto et al.) Macro-minerals determined were the hydroxyapatite crystals $\mathrm{Ca}$ and $\mathrm{P}$, while micro-minerals included $\mathrm{Na}, \mathrm{Fe}, \mathrm{Zn}$, and $\mathrm{Mg}$. The reason for identifying these elements is that bone is an anisotropic material composed by an organic phase constituting $35 \%$ of its dry weight and having type 1 collagen as its main component (90\%), with the remainder represented by proteoglycans, non-collagen proteins and water. The mineral phase $(65 \%)$ is composed by calcium phosphate crystals organized in a hidroxiapatite. Other non-crystal forming ions, such as zinc, magnesium, manganese, iron and cooper, are also found in bone and play an important role en bone catalytic functions (Jiménez-Palomar et al., 2012; Nicolae et al., 2011).

Histology. Histological staining to determine bone characteristics was used, following the method described by Schenk (Schenk et al., 1995)

a) Hematoxylin and eosin. Osteblasts deposit a non-calcified osteoid matrix forming trabecula of increasing width. The collagen secreted is deposited in randomly oriented fibers and forms reticular bone (collagen fibers running in all directions) (Chapman et al., 1997). Calcium salts are deposited on the extracellular matrix (i.e, calcification). The novo bone developed forms a non-mineralized bone matrix called osteoid.

b) Masson Trichrome Staining. Intra-membrane (or direct) ossification takes place directly on the connective tissue, forming the flat bones making-up the vault (base) of the skull. Mesenchyme condenses around vascularized connective tissue where the cells are attached by long protrusions. Collagen bundles are deposited on the intercellular spaces and remain embedded in the matrix (Safdar et al., 2005). The first sign of bone formation is the appearance of thicker matrix bands equidistant from the bone's blood vessels network.

c) Von Kossa Staining. Osteoblasts will further become osteocites and regulate mineralization, adequately arranging proteins and forming small depressions (100nm) surrounded 
SESMAN, A.; RUVALCABA, E.; HERRERA, A.; SÁNCHEZ, G. S.; LECONA, H.; BAENA-OCAMPO, L.; SOLIS, L.; ÁVILA, H.; GARCÍA DE LA PUENTE, S.; VARGAS, B.; GUERRERO, X. \& VELASQUILLO, C. Morphological study of bone cranial in athymic mice. Int. J. Morphol., 31(1):321-328, 2013.

partly by the plasma membrane all over the matrix. Osteoblast plasma membrane contains enzymes such as alkaline phosphatase that increases the local phosphate and calcium concentrations giving way to salt nucleation centers that make-up the mineral phase of the matrix (Greenwald et al., 2001).

Immunohistochemistry. The immunochemistry technique used complied with the method proposed by Sakou (1998). The purpose in this case was finding morphogenic proteins.

There are several important bone metabolism markers, such as the RUNX2 transcription factor, that allow to estimate bone differentiation and the capacity of forming a mineralized bone matrix by measuring type 1 collagen and calcium phosphate. The capacity to regulate remodeling processes can also be studied through the synthesis of specific enzymes, mainly alkaline phosphatase, and specific bone proteins, mainly osteocalcin and osteopontin. Hence, we considered that it was also possible to demonstrate the skull's characteristics in athymic mice by measuring these bonemetabolism markers.

a) Runx2. RUNX2 protein (also called CBFA1) is a key transcription factor linked to osteoblast differentiation. It is coded in humans by the runx 2 gene. RUNX2 belongs to the RUNX transcription factor family and has a binding-to-DNA Runt domain. The factor is essential in osteoblast differentiation and skeleton morphogenesis and acts as a structural protein for both the nucleic acids and the regulating factors involved in the gene expression related to the skeleton. This protein may bond to DNA either as a monomer or as heteromeric complex with a higher affinity (Dietmar et al., 2005).

b) Type 1 collagen . A protein consisting of 1678 aminoacids, codified by chromosome X. It is present abundantly in the skin, bone, tendon, dentin and cornea. It is arranged in bundles composed of striated fibers 20 to $100 \mathrm{~nm}$ in diameter. Its bigger sub-units consist of two types of alpha chains that differ slightly in terms of their constituting aminoacids and their sequence. Type 1 collagen is synthesized by fibroblasts, chondroblasts and osteoblasts. Collagen accounts for $90 \%$ of the bone organic matrix (Sweeney et al., 1993).

c) Alkaline phosphatase. An enzyme found in all tissues responsible for the dephosphorylation of several types of molecules such as nucleotides, proteins and alkaloids. Alkaline phosphatase concentrations are higher in bone, liver, placenta, intestines and kidneys. Both the increase and the decrease of its plasma concentration have a clinical significance. In the specific case of the bone, the enzyme favors the bone matrix hydrolysis as part of the remodeling process. It correlates to the osteoblastic activity and the calcium deposits in bone (White \& Shors, 1986).

d) Osteocalcin. A linear peptide hormone of 49 amino-acids produced by osteoblasts during bone formation and becoming an integral part of the bone matrix. It can bind to the hidroxyapatite. Osteocalcin levels positively correlate to the bone-formation ratio. It is considered a specific bonemetabolism marker (Ardila \& Martin, 2000).

e) Osteopontin. A highly phosphorylated sialoprotein capable that binds to calcium and has a high affinity for hydoxyapatite. It plays an important role in the bone mineralization and calcification processes and is a constituent of the bone matrix. It is produced by osteoblasts and participates in the remodeling of resorption areas created by osteoclasts. It can bind to hydroxyapatite in a way similar to that of fibronectin. It is considered a bone-metabolism marker (Ardila \& Martin; Wozney, 2002).

\section{RESULTS}

Electron Scanning Microscopy. Several cross-sections (four on average) by each of the processed skull samples were made. Table I shows the mean value and SD for all the samples summarized. Each percentage value refers to each of the minerals related to ossification found: sodium with a mean $(\mu)$ of 0.499 and SD of 0.3971 ; magnesium, $\mu 0.238$ and SD 0.2801; sulfur, $\mu 0.5355$ and SD 0.3312; iron, $\mu$ 0.176 and SD 0.1129; zinc, $\mu 0.115$ and SD 0.0892; phosphorus, $\mu 8.1125$ and SD 4.6354; and calcium, $\mu 16.385$ and SD 8.8377 .

The main minerals found in the bone of athymic mice skulls were calcium and magnesium, in a $2: 1$ ratio $(\mathrm{P}=8.11$ and $\mathrm{Ca} 16.38$ ), in agreement with the characteristics of skull bones and of any calcified tissue in vertebrates. Likewise, the percentages of other minerals found in this study, is also in agreement with bone normal characteristics in vertebrates, $(\mathrm{Na}=0.499 ; \mathrm{Mg}=0.238 ; \mathrm{S}=0.535 ; \mathrm{Fe}=0.176$ and $\mathrm{Zn}=0.115)$. From the Imaging standpoint, scanning microscopy bones characteristics express bone mineralization (calcium salts deposits on the extra-cellular matrix) (Fig. 1).

\section{Histology}

Hematoxylin and Eosin. The reason for the hematoxylineosin staining was to find de novo bone deposited as notcompletely-mineralized bone matrix (the osteoid tissue we were looking for precisely). We found trabecular bone, bone marrow and membranous stroma (Fig. 2). 
SESMAN, A.; RUVALCABA, E.; HERRERA, A.; SÁNCHEZ, G. S.; LECONA, H.; BAENA-OCAMPO, L.; SOLIS, L.; ÁVILA, H.; GARCÍA DE LA PUENTE, S.; VARGAS, B.; GUERRERO, X. \& VELASQUILLO, C. Morphological study of bone cranial in athymic mice. Int. J. Morphol., 31(1):321-328, 2013.

Table I. Electron Scanning Microscopy. Percentage of minerals deposited in the skulls of athymic mice.

\begin{tabular}{|c|c|c|c|c|c|c|c|}
\hline & $\mathrm{Na}$ & Mg & $\mathbf{S}$ & $\mathbf{F e}$ & $\mathbf{Z n}$ & $\mathbf{P}$ & $\mathrm{Ca}$ \\
\hline 1 & 0,29 & 0,13 & 0,36 & 0,09 & 0,05 & 6,07 & 10,73 \\
\hline 2 & 0,20 & 0,11 & 0,31 & 0,03 & 0,09 & 6 & 11,24 \\
\hline 3 & 0,24 & 0,13 & 0,60 & 0 & 0 & 4,41 & 8,77 \\
\hline 4 & 0,22 & 0,07 & 0,39 & 0,21 & 0,1 & 9,67 & 20,95 \\
\hline 5 & 0,33 & 0,07 & 1,75 & 0,31 & 0,18 & 1,48 & 3,21 \\
\hline 6 & 0,35 & 0,07 & 0,76 & 0,06 & 0,05 & 3,22 & 7,05 \\
\hline 7 & 0,28 & 0,02 & 0,62 & 0,09 & 0,11 & 2,98 & 5,95 \\
\hline 8 & 0,28 & 0,08 & 0,49 & 0,06 & 0,09 & 3,69 & 6,89 \\
\hline 9 & 0,51 & 0,08 & 0,70 & 0,05 & 0,03 & 1,76 & 2,66 \\
\hline 10 & 0,31 & 0,13 & 0,30 & 0,1 & 0 & 6,90 & 12,64 \\
\hline 11 & 0,22 & 0,08 & 0,53 & 0,19 & 0,19 & 7,13 & 20,37 \\
\hline 12 & 0,36 & 0,15 & 0,48 & 0,21 & 0,10 & 8,77 & 17,59 \\
\hline 13 & 0,27 & 0,21 & 0,42 & 0,22 & 0,19 & 9,77 & 23,89 \\
\hline 14 & 0,30 & 0,14 & 0,35 & 0,44 & 0,37 & 7,86 & 26,6 \\
\hline 15 & 0,36 & 0,14 & 0,25 & 0,18 & 0,06 & 8,61 & 17,21 \\
\hline 16 & 0,79 & 0,47 & 0,35 & 0,23 & 0,07 & 14,72 & 26,98 \\
\hline 17 & 0,76 & 0,46 & 0,32 & 0,23 & 0,21 & 14,13 & 24,78 \\
\hline 18 & 1,58 & 0,98 & 0,75 & 0,26 & 0,09 & 15,08 & 26,06 \\
\hline 19 & 0,92 & 0,26 & 0,27 & 0,27 & 0,18 & 15,21 & 27,91 \\
\hline 20 & 1,41 & 0,98 & 0,71 & 0,29 & 0,14 & 14,79 & 26,22 \\
\hline MEDIA & 0,499 & 0,238 & 0,5355 & 0,176 & 0,115 & 8,1125 & 16,385 \\
\hline DS & 0,397199 & 0,280124 & 0,33121 & 0,112969 & 0,089207 & 4,635424 & 8,837772 \\
\hline
\end{tabular}

Masson Trichrome. Masson Trichromic staining was used to find ossified zones with calcium and phosphate deposits demonstrating the presence of bone tissue in the sample studied (Fig. 3).

Von Kossa Staining. Von Kossa staining allowed observation of the osteoid tissue trimming that begins to mineralize (dark red) and mineralized bone (dark areas) (Fig. 4).

Immunohistochemistry. RunX2. Runx2 showed moderate positivity (Fig. 5). Runx 2 is an osteoblastic transcription factor (osteoblasts to osteocites), the tissue analyzed is in the ossification process; hence, transcription of osteoblasts to osteocites is minimal and similar to the characteristics observed in normal skull.

Type 1 Collagen. Since collagen accounts for $90 \%$ of the organic matrix. Figure 6 confirms the presence of clear and proven positivity with this staining in the normal skull of athymic mice.
Alkaline Phosphatase. Since this enzyme determines the activity of osteoblastic cells by regulating bone calcium deposits, Figure 7 also allows shows clear positivity for the enzyme in ossification areas in athymic mice skull.

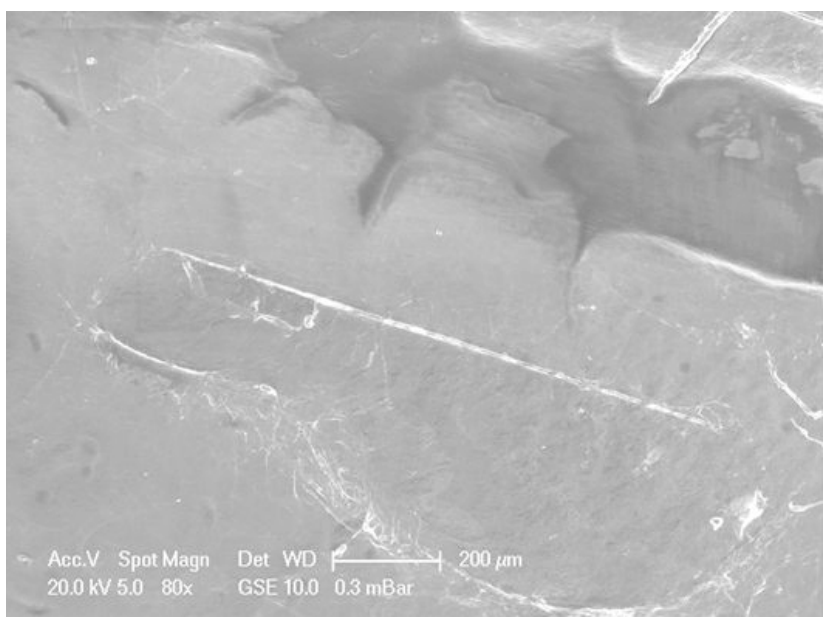

Fig. 1. Scanning microscopy of athymic mice skulls. 


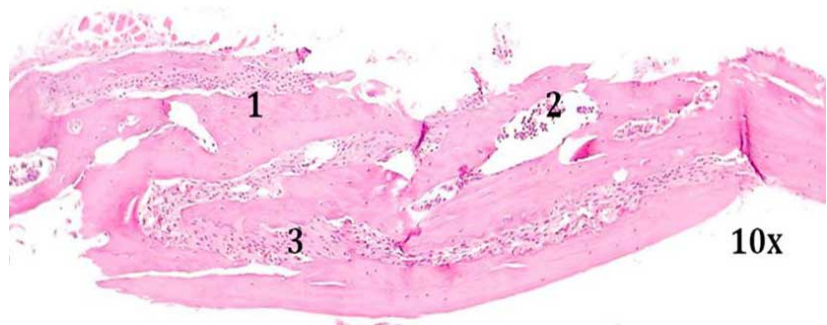

Fig. 2. Panoramic view of athymic mice skull, trabecular bone. 1. Normal cellularity with neoformation zone; 2 . Bone marrow with hematopoietic elements; 3 . Membranous stroma with fibroblasts and blood vessels. HE.

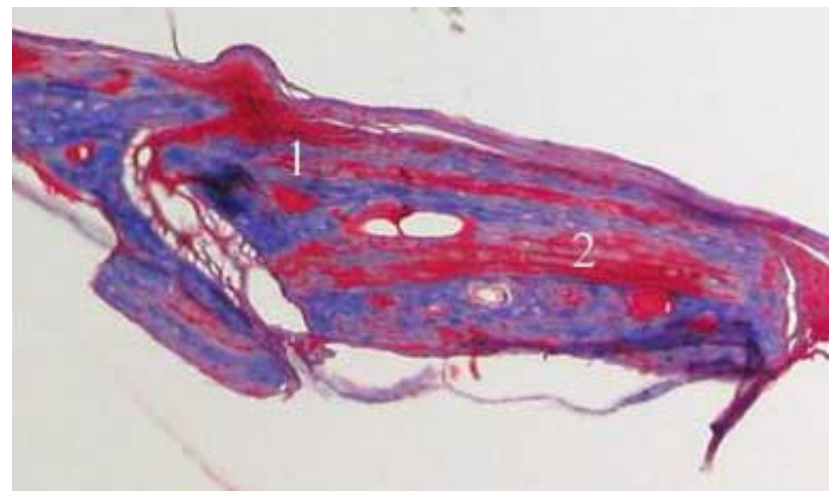

Fig. 3. Panoramic view of athymic mice skull. 1. Ossified tissue forming trabecula; 2 . Tissue in ossification process. Trichrome Masson.

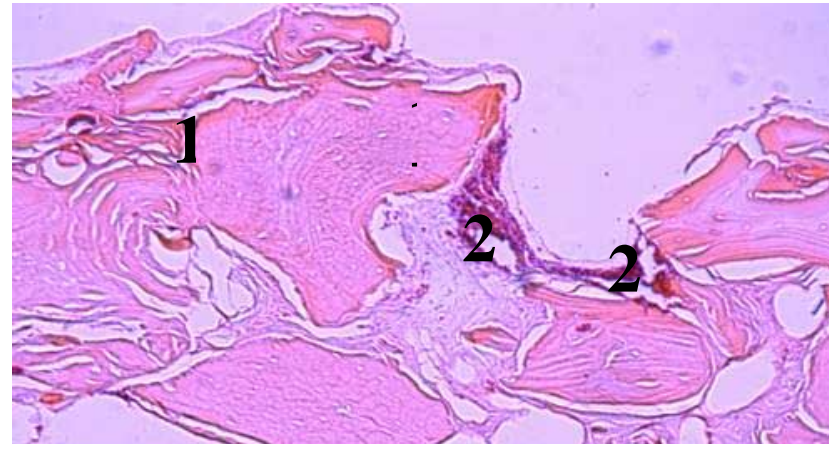

Fig. 4. Panoramic view of athymic mice skull. 1. Osteoid tissue becoming mineralized; 2. Mineralized bone. Von Kossa.

Osteocalcin. Positivity is also observed to osteocalcin in Figure 8 . The protein is present in the bone-formation tissue of athymic mice skull.

Osteopontin. Figure 9 shows intense positivity for osteopontin demonstrating the presence of hydroxyapatite crystals and the bone-remodeling process in athymic mice skulls.

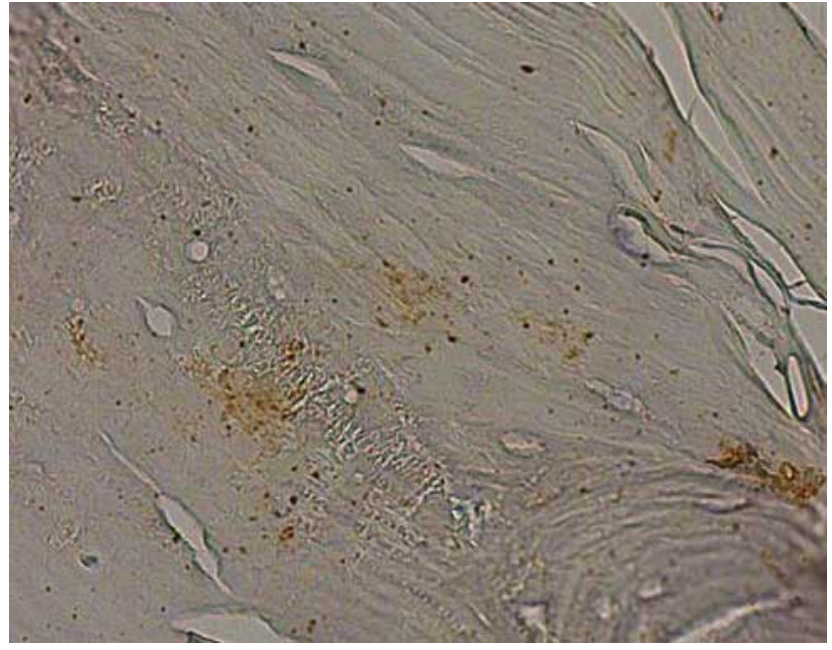

Fig. 5. Moderate positivity with immunohistochemical staining using Runx 2 in athymic mice skull.

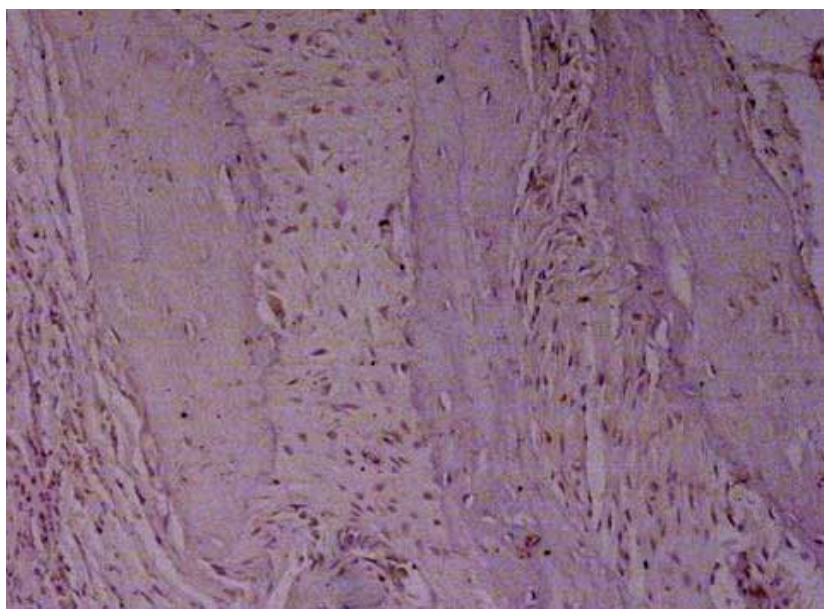

Fig. 6. Proven type 1-collagen-positive bone using immunohistochemical staining in athymic mice skull.

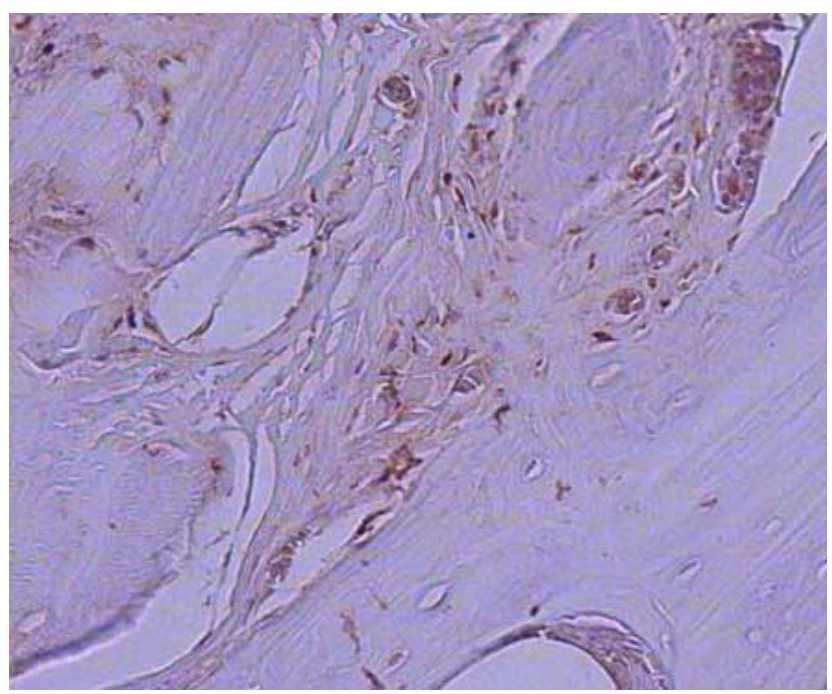

Fig. 7. Alkaline-phosphatase-positive ossification areas in athymic mice skull. 


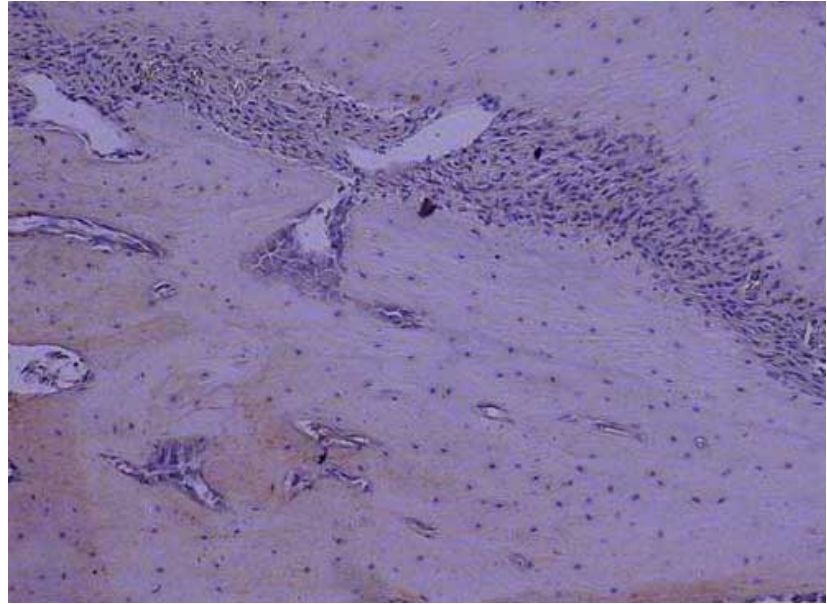

Fig. 8. Diffuse positivity for osteocalcin in immunohistochemistry staining in bone from athymic mice skulls.

\section{DISCUSSION}

Because of the constant increasing demand for bone to be used in the treatment of cranial and other bones defects, autologous bone graft options have been designed. Though the most widely used are allografts and xenografts, synthetic alternatives known as bone substitutes are currently been developed. Ideally, these substitutes must be biocompatible, biodegradable, osteoconducive, osteoinductive and possess a structure similar to bone, easy to use and affordable. These products vary in terms of their composition, action mechanism and effectiveness and its application must be based on the function we want to perform and on the previous assessment of the setting they will be placed on, as well as on the studies supporting their safety. It is reasonable to believe that combinations of these materials will provide better results than the autologous bone graft. In the next few years, a gold standard will be developed for these substitutes. Finding this standard is the aim of our studies (Gazdag et al., 1995; Safdar et al.; Boden, 2003).

It is precisely with the purpose in mind of finding a material for substituting autologous bone graft, our gold standard, that we devoted our efforts to find an osteogenic unit with characteristics similar to that of autologous bone (Orban et al.; Wozney et al.; Sonobe et al.; Urist, 1965).

To design this osteogenic unit, it was first necessary to determine the normal characteristics of the skulls of athymic mice. After an extensive literature review, we found that the best way to demonstrate the bone specifications and characteristics of athymic mice skulls was using electron scanning microscopy, as described by Basurto et al., in their study of bone consolidation. It was precisely through

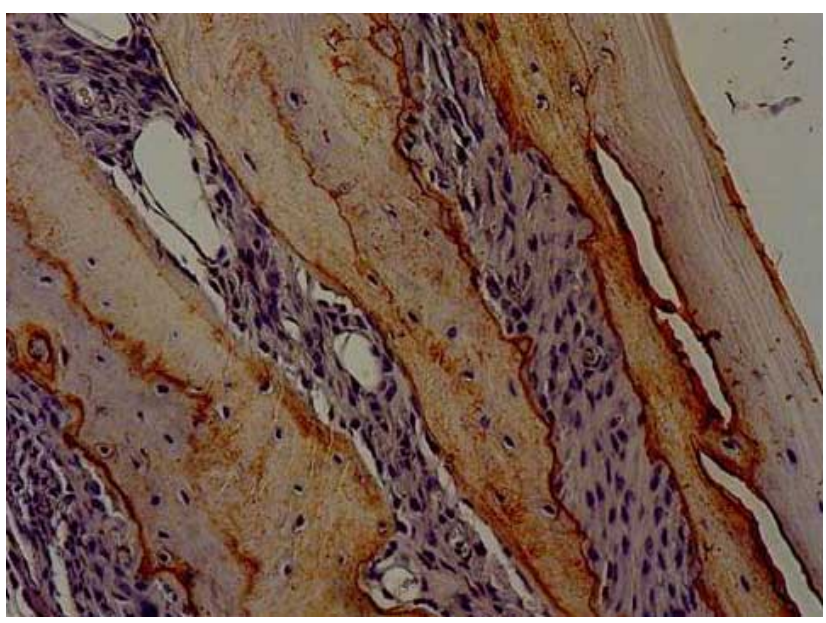

Fig. 9. Immunohistochemistry: intense positivity for osteopontin.

scanning microscopy that we found the presence of calcium and phosphorus, in a 2:1 ratio, as well as other minerals such as sodium, magnesium, zinc, etc., hence determining that this bone possesses the characteristics of a normal tissue. When analyzing this athymic mice bone tissue, using the method described by Schenk in his study of bone regeneration pattern, we observed trabecular bone, normal cellularity with de novo bone, bone marrow with hematopoietic elements, membranous stroma with fibroblasts and blood vessels when using hematoxylin-eosin staining. (Schenk et al.) Masson Trichrome staining allowed the observation of trabecula-forming ossified bone and inossification process bone. When this bone was studied using the Von Kossa staining, osteoid tissue beginning to mineralize and already mineralized bone were apparent. Finally, it was the immunohistochemical staining that allowed the search for morphogenic proteins, such as osteopontin and osteocalcin. Using the method described by Sakou et al., we found moderate positivity for Runx 2 transcription factor, an early marker of bone formation. The tissue analyzed in this study was already in the process of ossification. The other proteins studied, alkaline phosphatase, type 1 collagen, osteocalcin and osteopontin are all clearly positive in the tissue. All the aforementioned data allowed us to determine the characteristics of the bone as were never described before in the available literature.

CONCLUSIONS. Based on the aforementioned, we can conclude as follows:

Electron scanning microscopy of the studied tissue 
allowed us to observe the main mineral deposits involved in ossification as well as to establish their inter-relationships, e.g., a Calcium : Phosphate $2: 1$ ratio that agrees with the normal bone characteristics.

- Histological staining showed the presence of osteoid tissue, in-mineralization process tissue and mineralized tissue, i.e., bone deposits and remodeling of normal characteristics.
- The immunohistochemistry assay showed all stains were positive to proteins related to bone tissue, such as Runx2, type 1 collagen, alkaline phosphatase, osteocalcin and osteopontin.

We finally conclude that the data analyzed will be useful when comparing this tissue with the tissue we can form with our proposed osteogenic unit.

SESMAN, A.; RUVALCABA, E.; HERRERA, A.; SÁNCHEZ, G. S.; LECONA, H.; BAENA-OCAMPO, L.; SOLIS, L.; ÁVILA, H.; GARCÍA DE LA PUENTE, S.; VARGAS, B.; GUERRERO, X. \& VELASQUILLO, C. Estudio morfológico de hueso craneal en ratones atímicos. Int. J. Morphol., 31(1):321-328, 2013.

RESUMEN: Propusimos la realización de una unidad osteogénica a desarrollar en cráneo de ratones atímicos, Sin embargo, nos enfrentamos al reto de encontrar datos que nos determinaran cuales eran las características morfológicas, inmunohistoquímicas y microtopográficas del cráneo de estos ratones atímicos, que nos sirvieran como referencia de normalidad y tener un punto de comparación, en caso de que pudiéramos lograr la formación de hueso de novo, a partir de la unidad osteogénica que propusimos. El objetivo, de conocer la morfología del hueso normal de cráneo de ratones atímicos, fue desarrollar posteriormente una unidad osteogénica que reuniera las características de Osteogénesis, Osteoinducción y Osteoconducción, y, compararlas contra las que tiene dicho hueso normal durante su proceso de formación y remodelación. Así, realizamos un estudio piloto donde establecimos características morfológicas de hueso del cráneo de ratones atímicos, a través de tinciones histológicas específicas, con hematoxilina-eosina y von Kossa para buscar tejido osteoide y hueso mineralizado y Tricrómico de Massón para observar zonas osificadas. Además, analizamos el tejido óseo a través de inmunohistoquímica, con la finalidad de buscar marcadores de formación ósea como fosfatasa alcalina que es resultado del estímulo de la actividad osteoblástica; colágena 1, la cual es una proteína estructural de la matriz ósea; osteopontina, proteína sintetizada específicamente por osteoblastos que favorece la proliferación celular y la remodelación en defectos óseos; osteocalcina hormona peptídica producida por los osteoblastos durante la formación ósea y Runx 2 Factor de transcripción expresado por las células progenitoras que estimula la diferenciación ósea. Además, sometimos el tejido óseo a microscopía electrónica para determinar la presencia de depósitos de compuestos como calcio, fósforo y magnesio.

PALABRAS CLAVE: Osteogénesis; Osteoinducción; Osteoconducción.

\section{REFERENCES}

Ardila, M. \& Martin, C. Proteínas morfogenéticas óseas. Rev. Fed. Odontol. Colomb., (22):1-11, 2005.

Basurto, R. N.; Arrieta, L. S. \& Castrejón, H. V. Estudio de la consolidación ósea en rata por microscopía electrónica de barrido. Vet. Méx., 39(2):1-12, 2008.

Boden, S. Bone graft and fusion-enhancing substances: practical applications of gene therapy. In: Principles and Practice of Spine Surgery. Vaccaro, (ed.). Philadelphia, Mosby, 2003.

Chapman, M. W.; Bucholz, R. \& Cornell, C. Treatment of acute fractures with collagen-calcium phosphate graft material. A randomized clinical trial. J. Bone Joint Surg. Am., 79:495-502, 1997.

Connolly, J.; Guse, R.; Lippiello, L. \& Dehne, R. Development of an osteogenic bone marrow preparation. J. Bone Joint Surg. Am., 71:684- 91, 1989.

Cornell, C. N. Osteoconductive materials as substitutes for autogenous bone grafts. Orthop. Clin. North Am., 30:591-8, 1999.
Dietmar, W.; Hutmacher, R. \& García, A. Scaffold-based bone engineering by using genetically modified cells. Gene, 347:110, 2005.

Eppley, B. Experimental assessment of the revascularization of acellular human dermis for soft-tissue augmentation. Plast. Reconstr. Surg., 107:757-62, 2001.

Gazdag, A. R.; Lane, J. M.; Glaser, D. \& Forster, R. A. Alternatives to autogenous bone graft: efficacy and indications. J. Am. Acad. Orthoped. Surg., 3:1-8, 1995.

Greenwald, S.; Boden, S.; Goldberg, V.; Khan, Y. \& Laurencin, C. Bone graft substitutes: facts, fictions and applications. J. Bone Joint Surg., 83:S98-103, 2001.

Gronthos, S.; Zannettino, A.; Graves, S.; Ohta, S.; Hay, S. \& Simmons, P. Differential cell surface expression of the STOR-1 and alkaline phosphatase antigens on discrete-developmental sages in pimary cultures of human bone cells. J. Bone Miner. Res., (1):47-56, 1999. 
SESMAN, A.; RUVALCABA, E.; HERRERA, A.; SÁNCHEZ, G. S.; LECONA, H.; BAENA-OCAMPO, L.; SOLIS, L.; ÁVILA, H.; GARCÍA DE LA PUENTE, S.; VARGAS, B.; GUERRERO, X. \& VELASQUILLO, C. Morphological study of bone cranial in athymic mice. Int. J. Morphol., 31(1):321-328, 2013.

Harris, S. E.; Bonewald, L. F.; Harris, M. A.; Sabatini, M.; Dallas, S.; Feng, J. Q. et al. Effects transforming growth factor beta on bone nodule formation and expression of bone morphogenetic protein 2, osteocalcin, osteopontine, alkaline phosphatase, and type collagen mRNA in long term cultures of fetal rat calvarial osteoblasts. J. Bone Miner. Res., 9:855-6, 1994.

Herkowitz, H. N. A pilot study evaluating the safety and efficacy of OP-1 putty (shBMP-7) as a replacement for iliac crest autograft in posterolateral lumbar arthrodesis for degenerative spondylolisthesis. Spine, 29:1885-92, 2004.

Inoue, K.; Ohgushi, H.; Yoshikawa, T. et al. The effects of aging on bone formation in porous hydroxyapatite: biochemical and histologic analysis. J. Bone Miner. Res., 12:989-94, 1997.

Jimenez-Palomar, I.; Shipov, A.; Shahar, R. \& Barber, A. H. Influence of SEM vacuum on bone micromechanics using in situ AFM. $J$. Mech. Behav. Biomed. Mater., 5(1):149-55, 2012.

Lorenz, H. P.; Hedrick, M. H.; Chang, J.; Mehrara, B. J. \& Longaker, M. T. The impact of biomolecular medicine and tissue engineering on plastic surgery in the XXI Century. Plast. Reconstr. Surg., 5(7):245-9, 2000.

Mayer, U.; Joos, U. \& Wiesmann, P. Biological and biophysical principles in extracorporal bone tissue engineering. I. Int. J. Maxillofac. Surg., 33:325-32, 2004.

Nade, S.; Armstrong, L.; McCartney, E. \& Baggaley, B. Osteogenesis after bone marrow transplantation: the ability of ceramic materials to sustain osteogenesis from transplanted bone marrow cells: preliminary studies. Clin. Orthop., 181:255-63, 1983.

Nicolae, C.; Hîncu, M. \& Amariei, C. Scanning electron microscopic observation of morphological modifications produced by Fluorostom on bone surface. Rom. J. Morphol. Embryol., 52(4):1255-9, 2011.

Orban, J.; Marra, K. \& Hollinger, J. Composition options for tissue engineered bone. Tissue Eng., 8:529-39, 2002.

Safdar, N.; Khan, F, Cammisa, H. Jr.; Sandhu, S.; Ashish, D. et al. The biology of bone grafting. J. Am. Acad. Orthop. Surg., 13:77-86, 2005.

Sakou, T. Bone morphogenetic proteins: from basic studies to clinical approaches. Bone, 22: 591-603, 1998.

Schenk, R.; Buser, D.; Hardwick, R. \& Dahlin, C. Healing pattern of bone regenerationin membrane-protected defects: a histologic study in the canine mandible. J. Craniomasillofac. Surg., 23:133, 1995.

Sonobe, J.; Okubo, Y.; Kaihara, S.; Miyatake, S. \& Bessho, K. Osteoinduction by bone morphogenetic protein 2-expressing adenoviral vector: application of biomaterial to mask the host immune response. Hum. Gene Ther., 15:659-68, 2004.
Sweeney, T. M.; Chabra, A.; Brooke, B.; Opperman, L. A. \& Ogle, R. C. Type I collagen gels mediate total repair of bone defects through intramembranous ossification. J. Bone Joint Surg. Am., 76:922, 1994

Sweeney, T. M.; Opperman, L. A.; Persing, J. A. \& Ogle, R. C. Transplanted osteoblasts in type I collagen gels repair of critical size rat calvarial defects. Orthop. Trans., 16:785, 1993.

Urist, M. R. Bone formation by autoinduction. Science, 150:8939, 1965

White, E. \& Shors, E. C. Biomaterial aspects of interpore-200 porous hydroxyapatite. Dent. Clin. North Am., 30:49-67, 1986.

Wozney, J. M.; Rosen, V.; Celeste, A. J. et al. Novel regulators of bone formation: molecular clones and activities. Science, 242:1528-34, 1998.

Wozney, J. M. Overview of bone morphogenetic proteins. Spine, 27:S2-S8, 2002.

Correspondence to:

María Cristina Velasquillo Martínez

Tissue Engineering

Cell Therapy and Regenerative Medicine Unit, Biotechnology National Institute of Rehabilitation in Mexico City MEXICO

E-mail: mvelasquillo@inr.gob.mx

Received: 07-06-2012

Accepted: 30-11-2012 